\title{
FEATURES OF CYSTIC FIBROSIS COURSE IN CHILDREN DEPENDING ON INTERLEUKIN-4 GENE MUTATION
}

\author{
Drobova N. M.
}

\section{Kharkiv National Medical University, Ukraine}

\begin{abstract}
Cystic fibrosis (CF) course features depend not only on the difference in $\mathrm{CF}$ transmembrane conductance regulator gene mutations, but also on other gene modifiers. Interleukin-4 (IL-4) gene is a one of gene modifiers. The aim of the present study was to improve medical care for patients with CF by clarifying the pathogenic role of IL-4 gene polymorphism in the course of the disease. The study involved examination of 42 children with CF and 54 practically healthy children as control group. Patient examination was carried out by the standard methods in the remission period. Determination of C589T polymorphism of IL-4 gene was carried out using polymerase chain reaction in real time. DNA was isolated from buccal epithelium cells. Patients with IL-4 gene mutation (C589T) were characterized by more frequent primary manifestation of the respiratory signs, Staphylococcus aureus predominance within respiratory pathological microorganisms, the incidences of bronchiectasis and lung fibrosis, more severe liver lesions, elevated total serum immunoglobulin E level, elevated levels of the CD25 lymphocytes, circulating immune complex and reduced immunoglobulin A levels. The data demonstrate features of CF phenotype associated with IL-4 gene polymorphism.
\end{abstract}

Key words: children, cystic fibrosis, clinical and paraclinical features, interleukin-4 gene mutation.

Introduction. Cystic fibrosis (CF) is a hereditary disease characterized by variety of clinical manifestation depending not only on the difference in $\mathrm{CF}$ transmembrane conductance regulator gene mutations, but also on other gene modifiers [3, 13, 14, 22].

$\mathrm{CF}$ is characterized by lifelong inflammation [10]. The study of the influence of inflammatory factors on genetic defects is of great scientific interest. Scientists have identified a number of genes modifiers that influence CF severity (interleukin (IL)-1B, IL-4, IL-10 genes, tumor necrosis factor- $\alpha$ (TNF- $\alpha)$, transforming growth factor $\beta 1$, mannose-binding lectin, $\alpha-1$-antitrypsin etc.) $[4,5,8,13,21,24]$. For example, IL-10 gene polymorphism (G1082A) is associated with Aspergillus fumigatus colonization, which has a significant role on the bronchopulmonary inflammation development [13]. Conversely, TNF- $\alpha$ gene polymorphism is associated with a

Corresponding Author:

Nadiia Drobova, MD, PhD student.

Department of Fundamentals of Pediatrics No.2.

Kharkiv National Medical University, Ukraine.

E-mail:dn88n5@gmail.com milder course of $\mathrm{CF}$ and later colonization of Pseudomonas aeruginosa (P. aeruginosa) [13].

According to the scientists, C589T polymorphism of IL-4 gene is involved in the modification of various diseases. IL-4 is an antiinflammatory cytokine synthesized by activated T-helper type 2, basophils, mast cells, switches B-lymphocytes to immunoglobulin (Ig) class E production [15]. Replacement of $\mathrm{C}$ allele with $\mathrm{T}$ allele leads to a significant increase of the $\operatorname{IgE}$, which takes an important part not only in the development of allergic reactions, but also in protecting of the organism from infectious agents, which is very relevant for $\mathrm{CF}$ patients with the chronic bronchopulmonary inflammation $[2,9,12]$.

The authors note to the significant influence of the cytokines polymorphism on the CF course, depending on the presence of which the disease acquires distinctive features with the same mutation CFTR [7].

Genetic defects that are harmless for general population and not accompanied by pathological manifestations can have a significant effect on CF course $[1,6,13]$.

Determination of additional allelic genes that directly affect the CF phenotype provides an opportunity not only to expand scientific 
knowledge about the CF nature, but also to improve an individualized approach to compiling the patient's algorithm $[16,20]$.

2. PURPOSES, SUBJECTS and METHODS:

2.1 Purpose. To improve medical care for patients with CF by clarifying the pathogenic role of IL-4 gene polymorphism in the course of the disease.

Tasks of study:

1. To determine the clinical features of children with CF depending on IL-4 gene polymorphism.

2. To determine the features of the immune status of children with CF depending on IL-4 gene polymorphism.

\subsection{Subjects \& Methods}

The research was conducted in the pulmonology department of Kharkiv Regional Clinical Children's Hospital No. 1 in 2015-2017. Clinical and paraclinical examination of patient
The study was conducted with respect to human rights in accordance with the current legislation in Ukraine, in compliance with international ethical requirements and did not violate ethical norms in science and standards for conducting biomedical research.

The results were processed by the IBM SPSS Statistics software according to the methods of variance statistics. Statistical significance was the difference between the indicators at $p<0.05$.

\section{Conflict of interests}

There is no conflict of interests.

\section{RESULTS AND DISCUSSION}

The study involved examination of forty two children. CF was diagnosed by clinical and paraclinical characteristics and confirmed by the results of pilocarpine test. The examined patients were mainly boys $(66.7 \%)$. According to age, the majority of the children were of senior school age (Table 1).

Table 1

Distribution of children with CF by gender and age

\begin{tabular}{|c|c|c|c|c|c|c|c|c|c|c|}
\hline \multirow{2}{*}{ Gender } & \multicolumn{2}{|c|}{$\begin{array}{c}1 \text { year - } \\
2 \text { year } \\
11 \text { months } \\
29 \text { days }\end{array}$} & \multicolumn{2}{|c|}{$\begin{array}{c}3 \text { years - } \\
6 \text { years } \\
11 \text { months } \\
29 \text { days }\end{array}$} & \multicolumn{2}{|c|}{$\begin{array}{c}7 \text { years - } \\
11 \text { years } \\
11 \text { months } \\
29 \text { days }\end{array}$} & \multicolumn{2}{|c|}{$\begin{array}{c}12 \text { years - } \\
17 \text { years } \\
11 \text { months } \\
29 \text { days }\end{array}$} & \multicolumn{2}{|c|}{ Total } \\
\hline & $\mathrm{n}$ & $\%$ & $\mathrm{n}$ & $\%$ & $\mathrm{n}$ & $\%$ & $\mathrm{n}$ & $\%$ & $\mathrm{n}$ & $\%$ \\
\hline Boys & 4 & 80 & 3 & 50 & 12 & 85,7 & 9 & 52,9 & 28 & 66,7 \\
\hline Girls & 1 & 20 & 3 & 50 & 2 & 14,3 & 8 & 47,1 & 14 & 33,3 \\
\hline Total, $\mathrm{n}$ & \multicolumn{2}{|c|}{5} & \multicolumn{2}{|c|}{6} & \multicolumn{2}{|c|}{14} & \multicolumn{2}{|c|}{17} & \multicolumn{2}{|c|}{42} \\
\hline
\end{tabular}

with CF was carried out according to the Order of Ministry of Healthcare of Ukraine of 15 July 2016 No. 723 "On approval of the unified clinical protocol of primary, secondary (specialized) and tertiary (highly specialized) medical care "Cystic fibrosis", Order of Ministry of Healthcare of Ukraine of 29 January 2013 No. 59 "On approval of unified clinical protocols of medical care for children with diseases of the digestive system". Forty-two children with CF were observed. The control group (for assessment of immune analysis) consisted of 54 practically healthy children who had been randomized according to the age.

Determination of C589T polymorphism of IL-4 gene was carried out using polymerase chain reaction in real time. DNA was isolated from buccal epithelium cells using a special "DNAexpress" kit ("Liteh" company).

Investigation of immune status was carried out by the standard methods in the remission period. Total immunoglobulin E (Ig E) in serum was determined by solid phase enzyme-linked immunosorbent assay (ELISA).
During the study of C589T polymorphism in IL-4 gene in children with CF allele $\mathrm{T}$ was determined in 15 cases. Homozygotes for allele $\mathrm{T}$ and heterozygotes among patients with $\mathrm{CF}$ were significantly more prevalent in comparison with the control group (Table 2).

The majority of patients were boys in all groups of children who were included in the study (Fig. 1).

Clinical features were studied in the group of children with IL-4 gene mutation (homozygous and heterozygous patients) compared to patients without IL-4 gene mutation because of children distribution and a small number of patients with TT phenotype.

Group with CT+TT genotype was characterized by a more frequent primary manifestation of the respiratory signs, but not gastrointestinal, unlike general population of patients (Table 3).

Assessment of CF severity showed that moderate course prevailed in all the groups. CC genotype frequency was significantly higher in 
Table 2

Distribution of patients depending on C589T polymorphism of IL-4 gene

\begin{tabular}{|c|c|c|c|c|}
\hline \multirow{2}{*}{ Genotype } & \multicolumn{2}{|c|}{$\begin{array}{c}\text { CF patients group } \\
(\mathrm{n}=42)\end{array}$} & \multicolumn{2}{c|}{$\begin{array}{c}\text { Control group } \\
(\mathrm{n}=54)\end{array}$} \\
\cline { 2 - 5 } & $\mathrm{n}$ & $\%$ & $\mathrm{n}$ & $\%$ \\
\hline CC & 27 & $64.3^{*}$ & 45 & 83.3 \\
\hline CT & 11 & $26.2^{*}$ & 8 & 14.8 \\
\hline TT & 4 & $9.5^{*}$ & 1 & 1.9 \\
\hline Total, $\mathrm{n}$ & 42 & 100 & 54 & 100 \\
\hline
\end{tabular}

$*$ compared with control group $(\mathrm{p}<0.05)$.

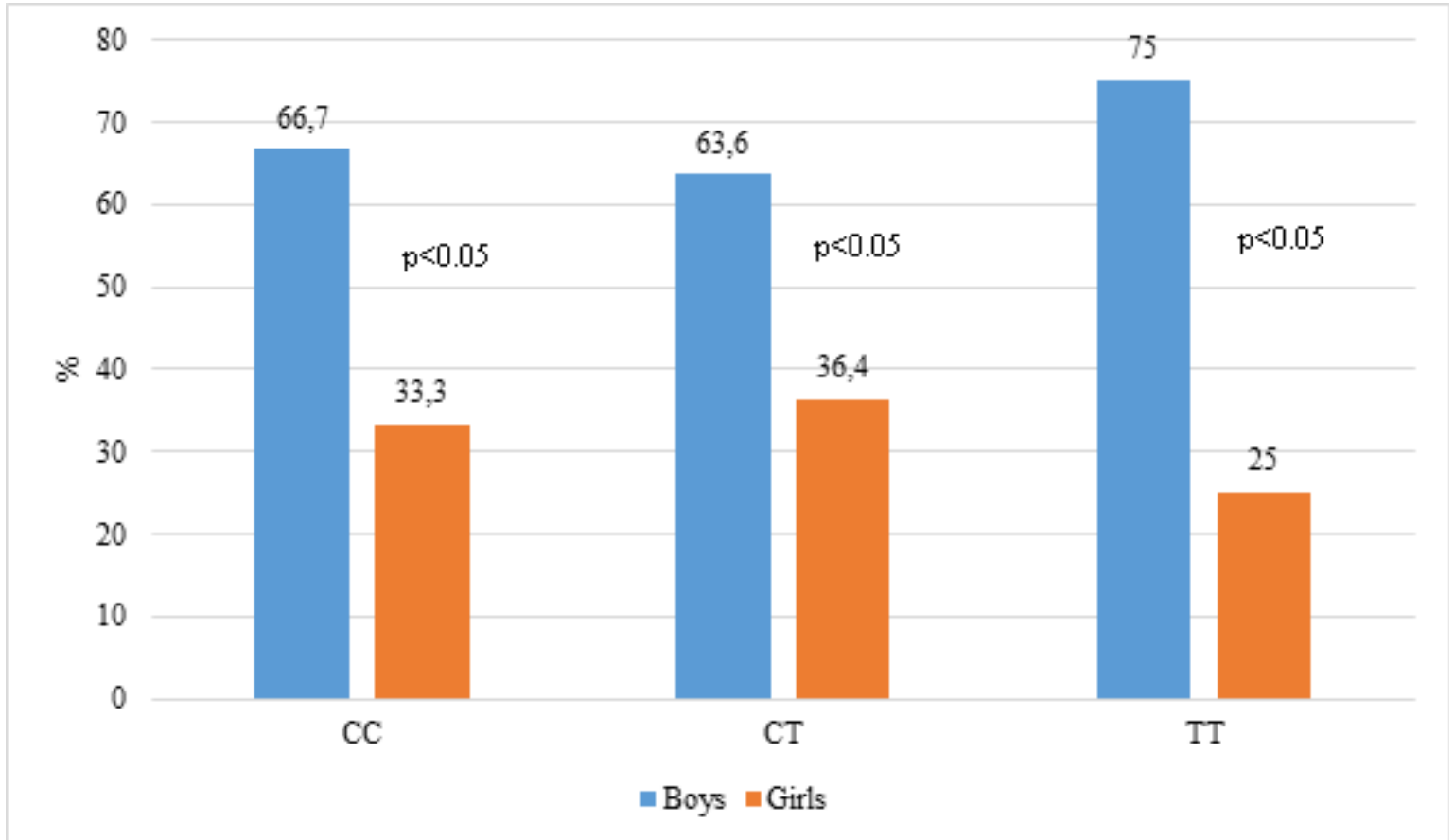

Fig. 1. Distribution of patients with CF by gender depending on C589T polymorphism of IL-4 gene

patients with mild course. $\mathrm{CT}+\mathrm{TT}$ genotype group was characterized by significantly higher frequency in patients with severe course (Fig. 2).

The incidence of bronchiectasis and lung fibrosis was significantly higher in the $\mathrm{CT}+\mathrm{TT}$ genotype group $(66.7 \%$ and $100 \%$ vs $25.9 \%$ and $65.9 \%$ respectively).

The study of hepatic disorders showed that cirrhotic changes in liver parenchyma were more common in patients with IL-4 gene mutation (Table 4).
Bacteriological tests showed Staphylococcus aureus (S. aureus), P. aeruginosa, Candida albicans (C. albicans) were identified as predominant pathological microorganisms in the CT + TT genotype group (Fig. 3).

More frequent primary manifestation of the respiratory signs, $\mathrm{S}$. aureus predominance within respiratory pathological microorganisms, more severe respiratory system and the liver lesions were found in the study of clinical features depending on C589T polymorphism of IL-4 gene.

Table 3

Manifestation of CF signs depending on C589T polymorphism of IL-4 gene

\begin{tabular}{|r|c|c|}
\hline \multirow{2}{*}{ Signs } & $\begin{array}{c}\text { CCnotype } \\
(\mathrm{n}=27)\end{array}$ & \multicolumn{1}{c|}{$\begin{array}{c}\text { CT+TT } \\
(\mathrm{n}=15)\end{array}$} \\
\hline & $\%$ & $\%$ \\
\hline gastrointestinal & 74,07 & 53,4 \\
\hline respiratory & 25,93 & $46,6^{*}$ \\
\hline
\end{tabular}

* compared with CC genotype group $(\mathrm{p}<0.05)$. 


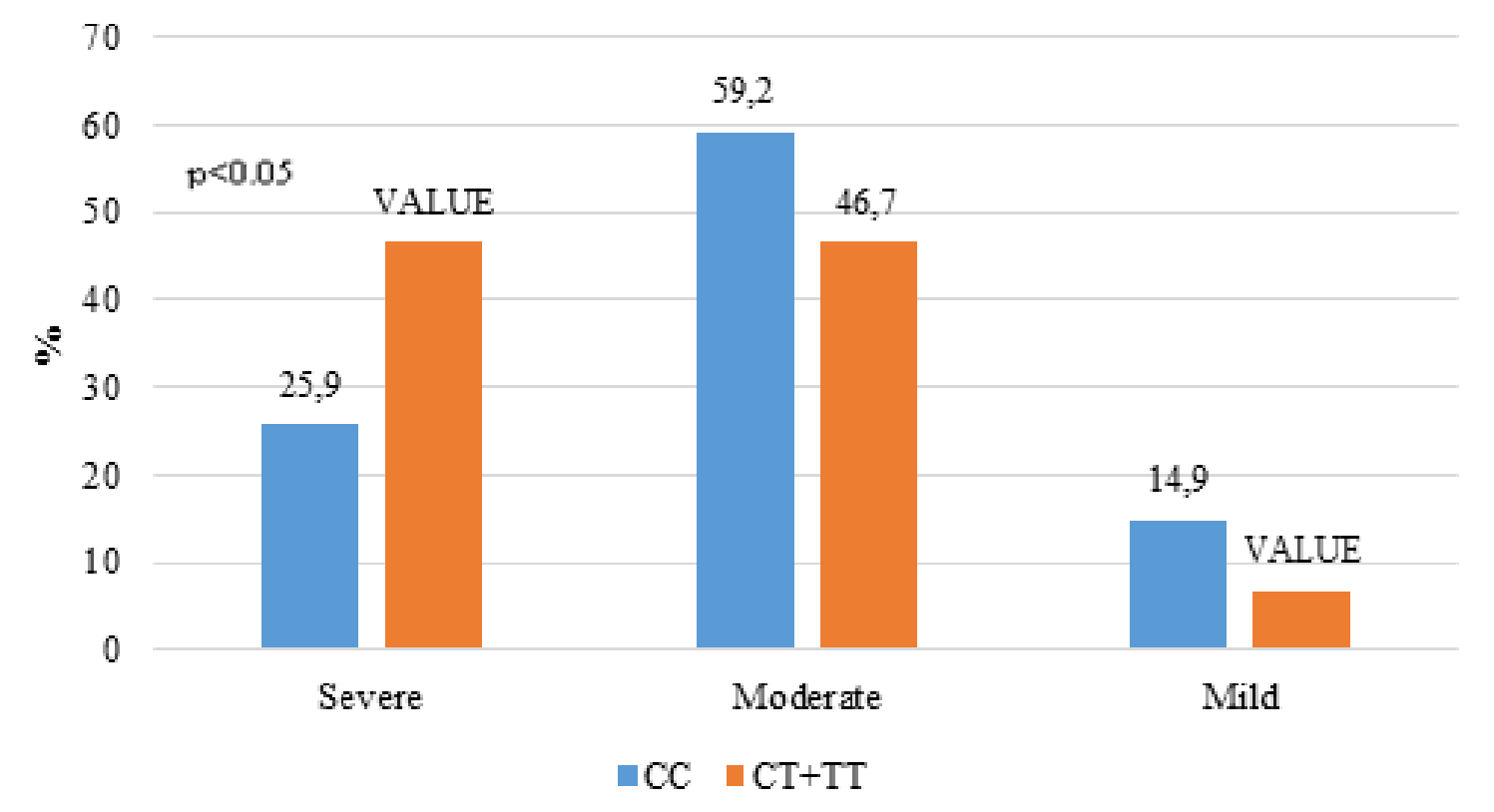

Fig. 2. The severity of CF course depending on C589T polymorphism of IL-4 gene

Elevated levels of CD25, circulating immune complex (CIC) and reduced IgA levels were found in patients of group with $\mathrm{CT}+\mathrm{TT}$ genotype during the study of immune status (Table 5, Fig. 4).

The mean value of the total serum IgE was $344.6(63.8 ; 670.3) \mathrm{IU} / \mathrm{ml}$.

Elevated total serum IgE level frequency $(80 \%)$ was significantly higher in the CT + TT genotype group (446.9 (187.82; 884.72) IU/ml), when the $\mathrm{CC}$ genotype group was characterized by results within the age range (74\%).

\section{Discussion}

C589T polymorphism of IL-4 gene affects the course of many diseases. For example, some authors described the negative effect of C589T polymorphism of IL-4 gene on the development of coronary artery disease [12].

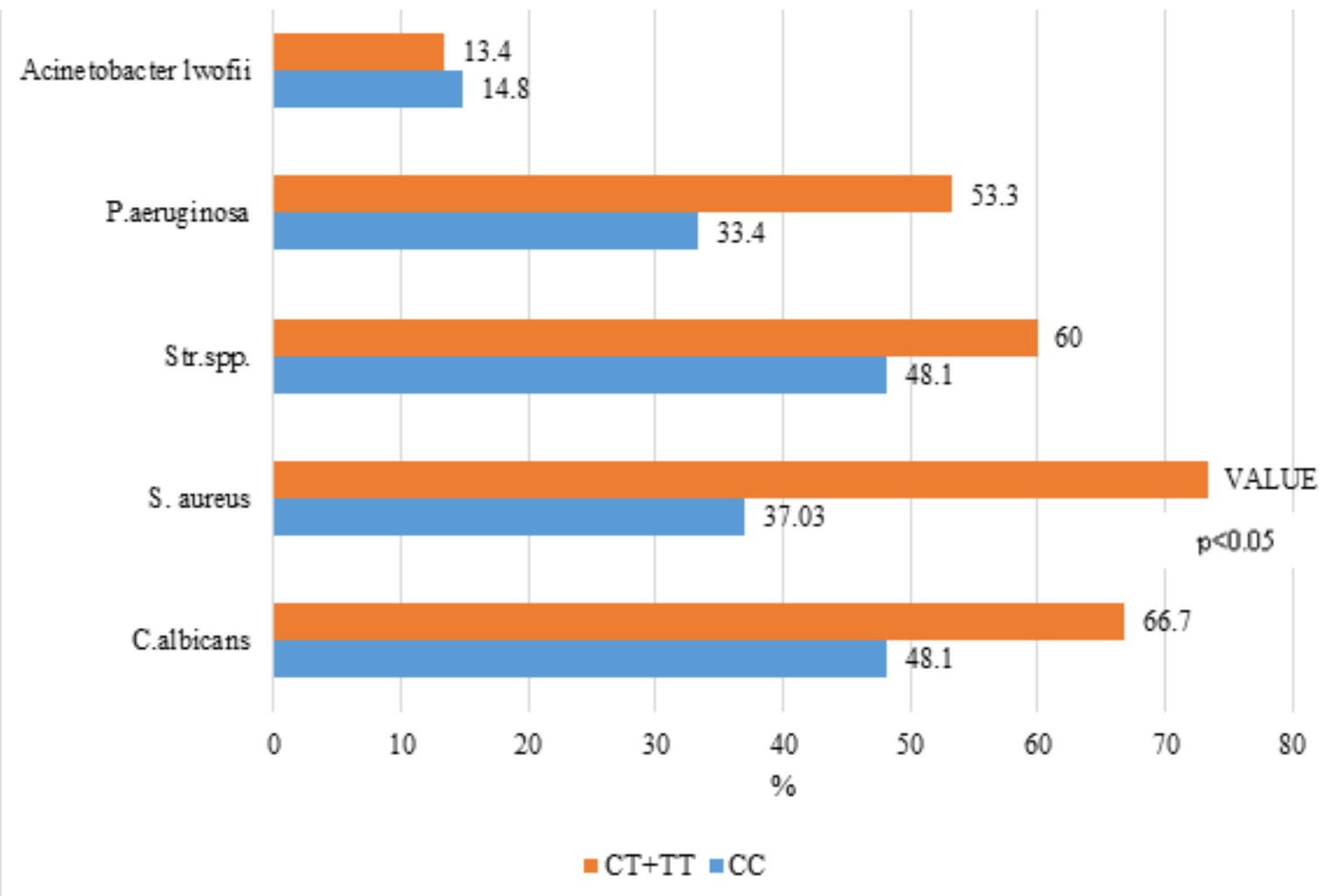

Fig 3. Indices of bacteriological tests depending on C589T polymorphism of IL-4 gene 
Table 4

The degree of hepatic disorder depending on C589T polymorphism of IL-4 gene

\begin{tabular}{|c|c|c|}
\hline \multirow{2}{*}{ Genotype } & $\begin{array}{c}\text { CC } \\
(\mathrm{n}=27)\end{array}$ & $\begin{array}{c}\text { CT+TT } \\
(\mathrm{n}=15)\end{array}$ \\
\cline { 2 - 3 } & $\%$ & $\%$ \\
\hline The degree dhepatic disorder & 29.6 & $6.6^{*}$ \\
\hline Norm & 62.9 & $46.7^{*}$ \\
\hline Cirrhotic changes & 7.5 & $46.7^{*}$ \\
\hline
\end{tabular}

*compared with CC genotype group $(\mathrm{p}<0.05)$.

Table 5

Indices of immunological status of children with CF depending on C589T polymorphism of IL-4 gene

\begin{tabular}{|c|c|c|c|c|c|c|}
\hline \multirow[b]{2}{*}{ Indicator } & \multicolumn{3}{|c|}{ IL-4 gene genotype } & \multirow[b]{2}{*}{$\mathbf{p}_{1}$} & \multirow[b]{2}{*}{$\mathbf{p}_{2}$} & \multirow[b]{2}{*}{$\mathbf{p}_{3}$} \\
\hline & $\begin{array}{c}C C \\
(n=27)\end{array}$ & $\begin{array}{l}\text { CT+TT } \\
(n=15)\end{array}$ & $\begin{array}{c}\text { Control group } \\
(n=30)\end{array}$ & & & \\
\hline Leukocytes, $\times 10^{9} / \mathrm{I}$ & $\begin{array}{c}6.32 \\
(5.5 ; 7.9) \\
\end{array}$ & $\begin{array}{c}6.5 \\
(5.1 ; 7.5) \\
\end{array}$ & $\begin{array}{c}6.35 \\
(5.47 ; 7.0) \\
\end{array}$ & $p>0.05$ & $p>0.05$ & $p>0.05$ \\
\hline Neutrophils, \% & $\begin{array}{c}49.0 \\
(40.5 ; 61.0) \\
\end{array}$ & $\begin{array}{c}49.0 \\
(42.0 ; 56.0) \\
\end{array}$ & $\begin{array}{c}51.0 \\
(48.0 ; 63.0) \\
\end{array}$ & $p>0.05$ & $p>0.05$ & $p>0.05$ \\
\hline Lymphocytes, \% & $\begin{array}{c}50.0 \\
(42.0 ; 61.0)\end{array}$ & $\begin{array}{c}51.0 \\
(44.0 ; 58.0)\end{array}$ & $\begin{array}{c}43.0 \\
(36.5 ; 47.0)\end{array}$ & $p>0.05$ & $p<0.05$ & $p<0.05$ \\
\hline CD 3, \% & $\begin{array}{c}69.0 \\
(65.5 ; 69.0) \\
\end{array}$ & $\begin{array}{c}66.0 \\
(63.0 ; 70.0) \\
\end{array}$ & $\begin{array}{c}61.0 \\
(58.7 ; 69.0) \\
\end{array}$ & $p>0.05$ & $p>0.05$ & $p>0.05$ \\
\hline CD 4, \% & $\begin{array}{c}40.0 \\
(38.0 ; 40.0) \\
\end{array}$ & $\begin{array}{c}39.0 \\
(37.0 ; 41.0) \\
\end{array}$ & $\begin{array}{c}44.0 \\
(39.0 ; 48.0) \\
\end{array}$ & $p>0.05$ & $p>0.05$ & $p>0.05$ \\
\hline CD 8, \% & $\begin{array}{c}28.0 \\
(27.0 ; 29.0) \\
\end{array}$ & $\begin{array}{c}27.0 \\
(29.0 ; 29.0) \\
\end{array}$ & $\begin{array}{c}30.0 \\
(29.0 ; 32.0) \\
\end{array}$ & $p>0.05$ & $p>0.05$ & $p>0.05$ \\
\hline CD 16, \% & $\begin{array}{c}14.0 \\
(10.0 ; 15.0) \\
\end{array}$ & $\begin{array}{c}12.0 \\
(9.0 ; 16.0) \\
\end{array}$ & $\begin{array}{c}14.0 \\
(13.75 ; 15.0) \\
\end{array}$ & $p>0.05$ & $p>0.05$ & $p>0.05$ \\
\hline CD 22, \% & $\begin{array}{c}19.0 \\
(18.0 ; 20.5) \\
\end{array}$ & $\begin{array}{c}19.0 \\
(17.0 ; 21.0)\end{array}$ & $\begin{array}{c}18.0 \\
(17.0 ; 20.0)\end{array}$ & $p>0.05$ & $p>0.05$ & $p>0.05$ \\
\hline CD 25, \% & $\begin{array}{c}21.0 \\
(19.0 ; 37.0) \\
\end{array}$ & $\begin{array}{c}26.0 \\
(17.0 ; 37.0) \\
\end{array}$ & $\begin{array}{c}17.0 \\
(14.0 ; 22.0) \\
\end{array}$ & $p<0.05$ & $p<0.05$ & $p<0.05$ \\
\hline $\begin{array}{l}\text { Phagocytosis of latex, } \\
\%\end{array}$ & $\begin{array}{c}63.0 \\
(59.0 ; 68.0) \\
\end{array}$ & $\begin{array}{c}61.0 \\
(54.0 ; 70.0) \\
\end{array}$ & $\begin{array}{c}60.0 \\
(54.0 ; 65.0) \\
\end{array}$ & $p>0.05$ & $p>0.05$ & $p>0.05$ \\
\hline Phagocytic number & $\begin{array}{c}3.8 \\
(3.7 ; 4.1) \\
\end{array}$ & $\begin{array}{c}3.7 \\
(3.54 ; 4.2) \\
\end{array}$ & $\begin{array}{c}3.5 \\
(3.3 ; 3.7) \\
\end{array}$ & $p>0.05$ & $p>0.05$ & $p>0.05$ \\
\hline $\begin{array}{l}\text { Total complement } \\
\text { (CH 50) }\end{array}$ & $\begin{array}{c}64.0 \\
(61.0 ; 65.0) \\
\end{array}$ & $\begin{array}{c}61.0 \\
(62.0 ; 68.0) \\
\end{array}$ & $\begin{array}{c}48.0 \\
(45.5 ; 52.0) \\
\end{array}$ & $p>0.05$ & $p>0.05$ & $p>0.05$ \\
\hline $\begin{array}{l}\text { CIC with } 3.5 \% \text { PEG, } \\
\text { units }\end{array}$ & $\begin{array}{c}7.6 \\
(6.4 ; 9.3) \\
\end{array}$ & $\begin{array}{c}8.3 \\
(7.0 ; 9.9) \\
\end{array}$ & $\begin{array}{c}7.95 \\
(6.8 ; 9.5) \\
\end{array}$ & $p<0.05$ & $p<0.05$ & $p<0.05$ \\
\hline $\begin{array}{l}\text { Spontaneous nitroblue } \\
\text { tetrazolium(NBT) } \\
\text { tests, \% }\end{array}$ & $\begin{array}{c}24.0 \\
(18.0 ; 42.0)\end{array}$ & $\begin{array}{c}28.0 \\
(17.0 ; 47.0)\end{array}$ & $\begin{array}{c}30.0 \\
(22.0 ; 32.0)\end{array}$ & $p>0.05$ & $p>0.05$ & $p>0.05$ \\
\hline $\begin{array}{l}\text { Spontaneous index of } \\
\text { activated neutrophils } \\
\text { (IAN) test, units }\end{array}$ & $\begin{array}{c}0.54 \\
(0.26 ; 0.81)\end{array}$ & $\begin{array}{c}0.53 \\
(0.27 ; 0.88)\end{array}$ & $\begin{array}{c}0.58 \\
(0.46 ; 0.8)\end{array}$ & $p>0.05$ & $p>0.05$ & $p>0.05$ \\
\hline Stimulated NBTest, \% & $\begin{array}{c}63.0 \\
(52.0 ; 68.0) \\
\end{array}$ & $\begin{array}{c}67.0 \\
(62.0 ; 72.0) \\
\end{array}$ & $\begin{array}{c}55.0 \\
(49.7 ; 70.0) \\
\end{array}$ & $p>0.05$ & $p>0.05$ & $p>0.05$ \\
\hline $\begin{array}{l}\text { Stimulated IAN test, } \\
\text { units }\end{array}$ & $\begin{array}{c}1.33 \\
(1.12 ; 1.49) \\
\end{array}$ & $\begin{array}{c}1.38 \\
(1.22 ; 1.49) \\
\end{array}$ & $\begin{array}{c}1.18 \\
(0.87 ; 1.29) \\
\end{array}$ & $p>0.05$ & $p>0.05$ & $p>0.05$ \\
\hline $\begin{array}{l}\text { Lysosomal cationic } \\
\text { proteins, units }\end{array}$ & $\begin{array}{c}1.18 \\
(1.01 ; 1.22) \\
\end{array}$ & $\begin{array}{c}1.19 \\
(1.08 ; 1.27) \\
\end{array}$ & $\begin{array}{c}1.12 \\
(0.93 ; 1.17) \\
\end{array}$ & $p>0.05$ & $p>0.05$ & $p>0.05$ \\
\hline $\lg A, g / l$ & $\begin{array}{c}1.38 \\
(1.02 ; 1.54) \\
\end{array}$ & $\begin{array}{c}1.23 \\
(0.99 ; 1.39) \\
\end{array}$ & $\begin{array}{c}1.18 \\
(0.83 ; 1.33) \\
\end{array}$ & $p<0.05$ & $p<0.05$ & $p<0.05$ \\
\hline $\lg M, g / l$ & $\begin{array}{c}1.02 \\
(0.83 ; 1.22) \\
\end{array}$ & $\begin{array}{c}0.98 \\
(0.85 ; 1.08) \\
\end{array}$ & $\begin{array}{c}0.97 \\
(0.64 ; 1.2) \\
\end{array}$ & $p>0.05$ & $p>0.05$ & $p>0.05$ \\
\hline $\lg G, g / l$ & $\begin{array}{c}10.38 \\
(10.28 ; 10.98) \\
\end{array}$ & $\begin{array}{c}10.29 \\
(9.66 ; 10.64) \\
\end{array}$ & $\begin{array}{c}10.09 \\
(8.53 ; 10.9)\end{array}$ & $p>0.05$ & $p>0.05$ & $p>0.05$ \\
\hline
\end{tabular}

$\mathrm{p}_{1}$ - CC genotype compared with the CT+TT genotype, $\mathrm{p}_{2}-\mathrm{CC}$ genotype compared with the control group, $\mathrm{p}_{3}-\mathrm{CT}+\mathrm{TT}$ genotype compared with the control group. 


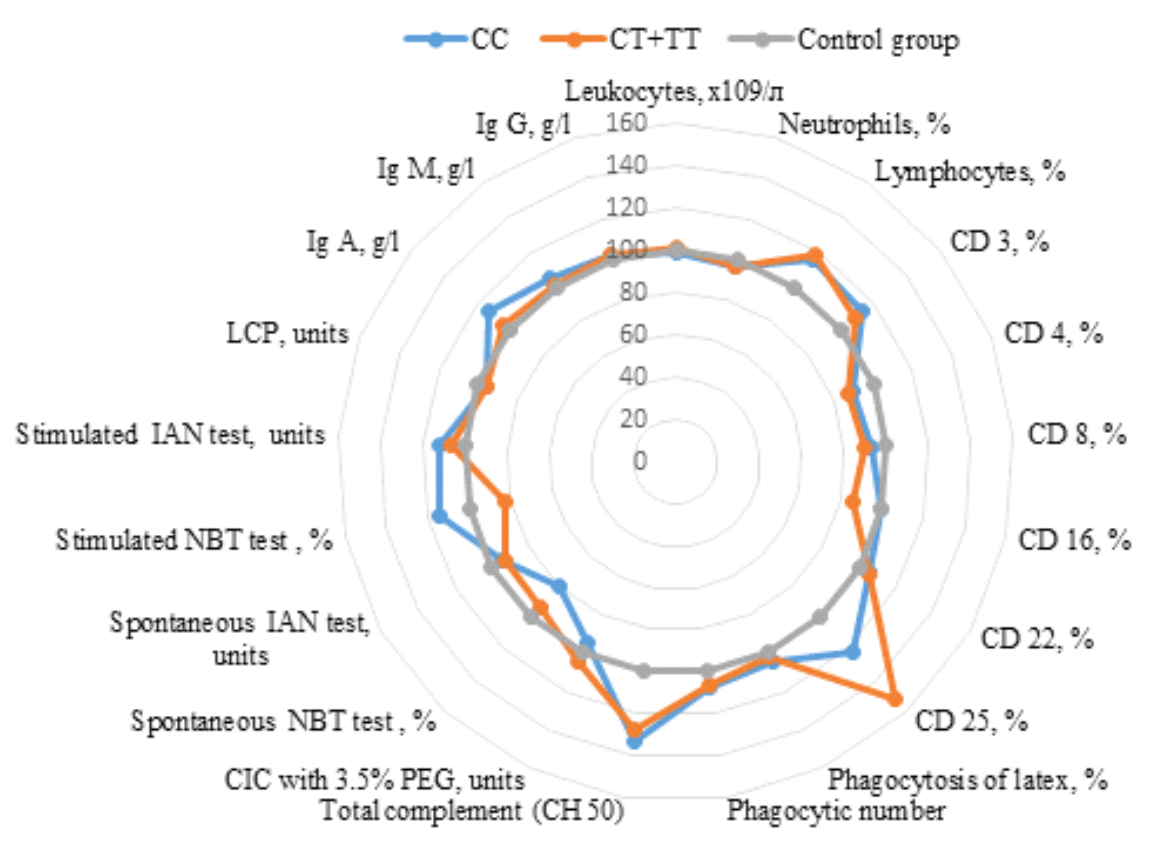

Fig. 4. Indices of immunological status of children with CF depending on C589T polymorphism of IL-4 gene

C589T polymorphism of IL-4 gene is associated with an elevated level of total $\mathrm{IgE}$ and bronchial hyperactivity in patients with bronchial asthma, which is an aggravating factor $[17,18]$.

There are not numerous studies regarding the influence of the IL-4 gene polymorphism the on CF. In this way, Sergienko DF and co-authors noted the relationship of 3'-UTR G/C mutation of IL-4 gene with the course severity of the bronchopulmonary inflammatory process [19].

Gembitskaya T.E. and co-authors studied the influence of IL-4 gene (C589T) mutation and its receptor (?-chain gene-IL-4R?) on the course severity of CF in the adult population (37 patients). Significant associations were not identified between polymorphic variants of IL-4 receptor gene and CF course, but the dependence of the clinical features on the IL-4 gene mutation was determined. It was found that homozygotes for $\mathrm{T}$ allele were only women [11].. According to our study, the influence of the C589T polymorphism of the IL-4 gene on the CF course severity was confirmed, but boys were dominated among patients with TT genotype.

Further research of the inflammatory genes modifiers will provide an opportunity to broaden knowledge about the peculiarities of the CF pathogenesis and mark new factors, which take part in the disease modification.

\section{Conclusion.}

Features of the CF phenotype associated with the polymorphism of the IL-4 gene were analyzed. More frequent primary manifestation of the respiratory signs, $\mathrm{S}$. aureus predominance within respiratory pathological microorganisms, the incidence of bronchiectasis and lung fibrosis, more severe liver lesions, elevated total serum IgE level, elevated levels of the CD25 lymphocytes, CIC and reduced IgA levels were found in children with $\mathrm{CF}$ and C589T polymorphism of IL-4 gene.

\section{References}

1. Accurso, F. J., Marci K. Sontag, M. K. (2008). Gene modifiers in cystic fibrosis. Journal of Clinical Investigation, 118(3), 839-841. doi:10.1172/JCI35138

2. Bhagirath, A.Y., Li, Y., Somayajula, D. (2016). Cystic fibrosis lung environment and Pseudomonas aeruginosa infection. BMC Pulmonary Medicine, 16, 174. doi:10.1186/s12890-016-0339-5

3. Bombieri, C., Seia, M., Castellani, C. (2015). Genotypes and Phenotypes in Cystic Fibrosis and Cystic Fibrosis Transmembrane Regulator- Related Disorders. Seminars in Respiratory and Critical Care Medicine, 36, 180-193. doi: 10.1055/s-0035-1547318

4. Buranawut, K., Boyle, M.P., Cheng, S., Steiner, L.L., McDougal, K., Fallin, M.D., Merlo, C., Zeitlin, P.L., Rosenstein, B.J., Mogayzel Jr., P.J., Wang, X., Cutting, G.R. (2007). Variants in mannose- 
binding lectin and tumour necrosis factor alpha affect survival incystic fibrosis. Journal of Medical Genetics, 44, 209-14. doi: 10.1136/jmg.2006.046318

5. Chalmers, J.D., Fleming, G.B., Hill, A.T., Kilpatrick, D.C. (2011). Impact of mannose-binding lectininsufficiency on the course of cystic fibrosis: a review and meta-analysis. Glycobiology, 21, 271-82. doi.org/10.1093/glycob/cwq161

6. Cutting, G.R. (2010). Modifier genes in Mendelian disorders: the example of cystic fibrosis. Annals of the New York Academy of Sciences, 1214, 57-69. doi: 10.1111/j.1749-6632.2010.05879.x.

7. De Vries, L., Griffiths, A., Armstrong, D., Robinson, P.J. (2014). Cytokine gene polymorphisms and severity of CF lung disease. Journal of Cystic Fibrosis, 13(6), 699-705. doi: 10.1016/j.jcf.2014.04.007

8. Dorfman, R. (2012). Modifier gene studies to identify new therapeutic targets in cystic fibrosis. Current Pharmaceutical Design, 18, 674-82. doi: 10.2174/138161212799315920

9. During, G., Flume, P., Heijerman, H. (2012). Treatment of lung infection in patients with cystic fibrosis: current and future strategies. Journal of Cystic Fibrosis, 11 (6), 461-479. doi: 10.1016/ j.jcf.2012.10.004

10. Flume, P.A., Mogayzel, P.J.Jr, Robinson, K.A., Goss, C.H., Rosenblatt, R.L., Kuhn, R.J., Marshall, B.C. (2009). Cystic fibrosis pulmonary guidelines: treatment of pulmonary exacerbations. American Journal of Respiratory and Critical Care Medicine, 180(9), 802-808. doi: 10.1164/ rccm.200812-1845pp

11. Gembitskaya, T.E., Kelembet, N.A., Ivaschenko, T.E. (2006). Znachenie nekotoryih genovmodifikatorov v klinicheskom techenii i ishodah mukovistsidoza. [The significance of some modifier genes in the clinical course and outcome of cystic fibrosis]. Pulmonologiya, 1, 57-60.

12. Golimbet, V.E., Volel, B.A., Korovaitseva, G.I., Kasparov, S.V., Kondratiev, N.V., Kopylov, F.Yu. (2017). Assotsiatsiya vospalitelnyih genov s nevrotizmom, trevozhnostyu i depressiey u muzhchin $\mathrm{s}$ ishemicheskoy boleznyu serdtsa. [Association of inflammatory genes with neuroticism, anxiety and depression in male patients with coronary heart disease]. Zhurnal nevrologii i psihiatrii, 117 (3), 74-79. doi: $10.17116 /$ jnevro20171173174-79

13. Guillot, L., Beucher, J., Tabary, O., Le Rouzic, P., Clement, A., Corvol, H. (2014). Lung disease modifier genes in cystic fibrosis. The International Journal of Biochemistry \& Cell Biology, 52, 83-93. doi: 10.1016/j.biocel.2014.02.011.

14. Kapranov, N.I., Kashirskaya, N.Yu. (2014). Mucoviscidoz. [Cystic Fibrosis]. Moskva: Medpraktika.

15. Kostina, E.M., Molotilov, B.A., Levashova, O.A., Osipova, M.V. (2013). Izuchenie polimorfizma genov tsitokinov IL-4, IL-10, IL-17A i TNF- $\alpha$ u bolnyih s infektsionnozavisimoy bronhialnoy astmoy. [The study of polymorphism of cytokine genes IL-4, IL-10, IL-17A and TNF- $\alpha$ in patients with infectious dependent bronchial asthma]. Immunopatologiya, allergologiya, infektologiya, 1, 53-58.

16. O'Neal, W.K., Knowles, M.R. (2018). Cystic Fibrosis Disease Modifiers: Complex Genetics Defines the Phenotypic Diversity in a Monogenic Disease. Annual Review of Genomics and Human Genetics, 19. doi: 10.1146/annurev-genom-083117-021329

17. Rosenwasser, L.J. (1999). Promoter polymorphism in the candidate genes, IL-4, IL-9, TGFbeta1, for atopy and asthma. International Archives of Allergy and Immunology, 118(2-4), 268-70.

18. Rosenwasser, L.J., Klemm, J., Dresback, J.K., Inamura, H., Mascali, J.J., Klinnert, M., Borish, L. (1995). Promoter polymorphisms in the chromosome 5 gene cluster in asthma and atopy. Clinical \& Experimental Allergy, 2, 74-8.

19. Sergienko, D. F. (2011). Kliniko-patogeneticheskoe znachenie geneticheskih modifikatsiy i narusheniya immunoregulyatornyih mehanizmov u detey s mukovistsidozom. [Clinical-Pathogenetic Importance of Genetic Modifications and Infringement of Immunoregulatory Mechanisms in Children with Cystic Fibrosis]. (Avtoreferat dissertatsii na soiskanie uchenoy stepeni doktora meditsinskih nauk). Astrahanskaya gosudarstvennaya meditsinskaya akademiya Federalnogo agentstva po zdravoohraneniyu i sotsialnomu razvitiyu, Astrahan.

20. Weiler, C.A., Drumm, M.L. (2013). Genetic influences on cystic fibrosis lung disease severity. Frontiers in Pharmacology, 4, 40. doi: 10.3389/fphar.2013.00040

21. Yarden, J., Radojkovic, D., De Boeck, K., Macek, Jr M, Zemkova, D., Vavrova, V., Vlietinck J., Cassiman, J-J., Cuppens, H. (2005). Association of tumour necrosis factor alpha variants with the CF pulmonary phenotype. Thorax, 60, 320-5. doi: 10.1136/thx.2004.025262

22. Yokoyama, E., Ch?vez-Saldana, M., Orozco, L., Cuevas, F., Lezana, J.L., Vigueras-Villasenor, R.M., Rojas-Castaneda, J.C., Landero, D.A. (2018). Influence of SNPs in Genes that Modulate Lung Disease Severity in a Group of Mexican Patients with Cystic Fibrosis. Archives of Medical Research, 0188-4409 (18),30110-3. doi: 10.1016/j.arcmed.2018.04.010

Received: 11-Mar. - 2018 Accepted: 17-Jun. - 2018 